\title{
PURCHASING OF KNOWLEDGE-INTENSIVE BUSINESS SERVICES: \\ A CASE STUDY OF RELEVANT FACTORS
}

\author{
Eija-Liisa Heikka ${ }^{1}$, Mekhail Mustak $^{2}$ \\ ${ }^{1}$ Department of Marketing, Oulu Business School, Oulu, Finland \\ FI-90014, University of Oulu, Finland \\ Tel.: +358503795838 (mobile). Email: eija-liisa.heikka@oulu.fi \\ ${ }^{2}$ Department of Marketing and International Business, Turku School of Economics, Turku, \\ Finland \\ FI-20014, Turun yliopisto, Finland \\ Tel.: +358 2333 9559. E-mail: mekhail.mustak@utu.fi
}

M.Sc. (Econ. \& Bus.Adm.) Eija-Liisa Heikka is a doctoral candidate at Oulu Business School, University of Oulu, Finland. Her current research interests focus on knowledgeintensive business services, value propositions, business relationships, modularity, and health care. She has previously worked on the ModuServ research project researching modularity in business services to co-create value within collaborative networks. She is currently working on the Digital Health Revolution research project researching developing digital self-care services in health care through value propositions.

M.Sc. (Econ. \& Bus.Adm.) Mekhail Mustak is a doctoral candidate at Turku School of Economics, University of Turku, Finland. His research interests focus on customer participation, value creation processes, knowledge-intensive business services, and service innovation. He has published in Journal of Business and Industrial Marketing and Journal of Service Theory and Practice. He has previously worked in international supply chain services at the A. P. Moller-Maersk group, where he helped to manage the supply chain operations of Nike, Tesco Stores and J.C. Penney. 


\title{
PURCHASING OF KNOWLEDGE-INTENSIVE BUSINESS SERVICES: A CASE STUDY OF RELEVANT FACTORS
}

\begin{abstract}
Purchasing of knowledge-intensive business services (KIBS) is often a critical decision for business customers as it can affect their businesses in numerous ways, such as creating a competitive advantage or fulfilling financial and regulatory objectives. Hence, customers tend to make careful and systematic decisions to purchase these services, and it is both theoretically and managerially important to know the factors that influence these decisions. However, the extant research has not shed sufficient light on those factors. The purpose of this study is thus to explore the factors that influence customers' KIBS purchasing decisions. A qualitative case study is used to gain a multi-dimensional understanding of the issue. The findings reveal that several factors influence customers' purchasing decisions: convincing value propositions, perception of service quality, perception of potential risks, potential for customisation, quality customer relationships, individual preferences, geographic proximity and availability of information. The findings are discussed further, and the implications and limitations of the study are noted.
\end{abstract}

Keywords: service purchasing; knowledge-intensive business services; KIBS; supplier selection; business-to-business services. 


\section{INTRODUCTION}

In business-to-business markets, purchasing knowledge-based or professional services from external sources has become an increasingly common phenomenon, as customer organisations often require these external services to run their businesses smoothly and successfully (Atkinson and Bayazit, 2014; Hallikas et al., 2013; Kowalkowski et al., 2011; Matthyssens and Vandenbempt, 2008). Commonly known as knowledge-intensive business services (KIBS), these services include management consultancy, legal assistance, computer- and information-related services, accounting and auditing, specialised training, advertising and R\&D services, among others (Miles, 2005). When purchasing these services, customers tend to make cautious and careful decisions by considering multiple factors that play crucial roles in the business processes of customer organisations (Atkinson and Bayazit, 2014; Bettencourt et al., 2002). In this paper, the researchers explore the factors that influence business customers' decisions to purchase KIBS.

Purchasing of KIBS or professional services is often an important decision for a customer organisation as this can create long-term effects, both positive and negative, and it involves high levels of expenditure, risks and uncertainty (Hallikas et al., 2013; Verville et al., 2005). As Day and Barksdale (1994, p. 44) state, 'Selecting a professional service provider can be one of the most important decisions and potentially one of the costliest mistakes a client firm can make'. These decisions may affect several dimensions of the customer's business, including its customers' core competencies; organisational structure, resources and capabilities; business relationships; and revenue and profit functions (Valk and Rozemeijer, 2009; Fitzsimmons et al., 1998). Further, the 'purchase of these services has become a substantial element in a firm's total acquisition of external resources' (Valk and Rozemeijer, 2009, p. 3). Also, according to Makkonen et al. (2012), 'Any organizational buying situation involves the evaluation of a set of attributes [...] in a decision-making process on which a variety of factors influence'. Hence, a clear understanding of the factors that influence business customers' decisions regarding the purchasing of professional or knowledge-based services is extremely important for service providers and customer organisations alike (Hallikas et al., 2013; Day and Barksdale, 1994).

On a general level, previous research has focused on various dimensions of organisational outsourcing and purchasing, including general conceptual developments (e.g. Fitzsimmons et al., 1998; Sheth, 1973; Smeltzer and Ogden, 2002; Webster and Wind, 1972), factors that 
affect an individual's influence on organisational purchasing decisions (cf., Kohli, 1989), the length of time required to make major purchase decisions (e.g. Dholakia et al., 1993), the effect of word-of-mouth on buyers' behaviours (File et al., 1994), decision criteria and relationships (e.g. Eriksson and Vaghult, 2000; Lian and Laing, 2007; Sonmez and Moorhouse, 2010) and use of information technology (e.g. Ellram, 2002). Unfortunately, although Wittreich noticed as early as 1966 (p. 127) that 'the tried and true rules for buying goods do not work when applied to the buying of professional services', much of the existing literature on organisational purchasing focuses on the acquisition of physical resources, and the findings are not always applicable to KIBS purchases (Hallikas et al., 2013; Valk and Rozemeijer, 2009). Moreover, the few studies that examine the purchasing of professional or knowledge-intensive business services are either conceptual in nature (e.g. Day and Barksdale, 1994), and thus lacking in empirical evidence, or do not shed light on the issues that influence purchasing decisions. To gain a greater understanding of the dynamics and mechanisms of the purchasing of services in business-to-business markets, it is both academically and managerially important to explore and analyse the factors that influence the purchasing of KIBS. Against this backdrop, the purpose of this study is to empirically explore the factors that influence business customers' KIBS purchasing decisions.

By providing insights into the factors that influence business customers' purchasing decisions regarding KIBS, this study extends the theoretical knowledge about organisational purchasing of such services. These factors have been examined in the context of modular engineering and consulting services, thus allowing for the generation of context-specific knowledge. This study also has important practical implications: customer organisations may use the results to make better-informed decisions when purchasing KIBS from other organisations, while service providers can gain practical insights into the key factors that cause business customers to purchase their services.

This study is exploratory in nature and employs a qualitative case study method. Twentysix narrative interviews with both customers and service providers were conducted to gather empirical data. The primary data collected through the interviews were supplemented with secondary data such as meetings, workshops, company brochures and so on.

In the following sections, a succinct review of the existing relevant literature on the purchasing of KIBS is presented, followed by a description of the methodology used in this study. Then, the study's findings are presented. The last section includes further discussions 
about the findings, the theoretical and managerial implications, the limitations of this study and potential topics for future research.

\section{PURCHASING KIBS - LITERATURE REVIEW}

To operate successfully in the business-to-business market, both customers and service providers must understand the dynamics and mechanisms of the organisational purchasing process as well as the mechanisms associated with it (Miozzo and Grimshaw, 2005). Nevertheless, as Johnston and Lewin (1996) argued, gaining such understandings can be difficult as organisational purchasing is 'often a multiphase, multiperson, multidepartmental, and multiobjective process' (Johnston and Lewin, 1996, p. 1). In addition, the common embodying characteristics of services - namely intangibility, heterogeneity, simultaneity and perishability—make the purchasing more complex (Axelsson and Wynstra, 2002).

Below, we provide a succinct review of KIBS, followed by our existing knowledge of the purchasing of these types of services. However, we do not intend to provide a broad literature review here and limit our focus to the literature relevant to this study.

\section{1 Knowledge-intensive business services}

Knowledge-intensive business services are service organisations whose primary value propositions include knowledge-intensive inputs to the business processes of customer organisations (Miles, 2005). The service offerings or activities provided by these organisations are complex, based on professional knowledge and mainly performed by people with formal and specialised training and education. As suggested by Pardos et al. (2007), several factors are increasing the demand for KIBS, including new information and communication technologies that demand continuous adaptation from business organisations, an increased need for complex management mechanisms and legal assistance due to rapid internationalisations of the markets and service providers' ability to continuously create new knowledge.

As suggested by Hertog (2000, p. 505), KIBS firms depend on professional knowledgethat is, knowledge or expertise related to a specific (technical) discipline or functional 
domain. The term was first used by the European Commission in the NACE classification (a European Commission classification of economic activities) to denote a specific set of services and activities. KIBS play an increasingly important role in our society; they are growing quickly in response to other sectors' demands for knowledge to deal with changing technologies and social conditions (Miles, 2005). In spite of this, however, research concerning KIBS is scarce compared to research concerning manufacturing organisations (Muller and Doloreux, 2009).

The distinctive characteristics of KIBS are related to the knowledge intensity of their value propositions or core offerings. Based on knowledge intensity, three principal features of KIBS can be identified: (a) they depend on professional knowledge; (b) they either are themselves primary sources of information and knowledge or they use knowledge to (co-)create value propositions or core offerings to support their clients' value creation processes; and (c) they are of competitive importance and primarily serve other businesses (Miles et al., 1995). As noted by Pardos et al. (2007), these knowledge-based service activities require highly trained and qualified personnel from the service provider organisation. The services make crucial connections between information, new technologies, novel management mechanisms, customised production and sales techniques and new markets. After a purchasing contract is drafted between the customer and the service provider, KIBS often need to be customised to meet the customers' particular needs (Bettencourt et al., 2002). Further, by nature, KIBS tend to be more technical than consumer services due to the greater complexity of customers' organisational needs. This suggests that the factors that cause business customers to purchase KIBS may differ depending on the services being purchased (Fitzsimmons et al., 1998).

\subsection{Purchasing of knowledge-intensive business services}

The purchasing of KIBS or professional services can have a significant impact on the processual and functioning aspects of customer organisations 'since poor purchase decisions can lead to poor performance and, likewise, good decisions to good performance' (Valk and Rozemeijer, 2009, p. 3). The collaboration-based 'relational' approach to purchasing, which focuses on joint planning, collaboration, trust and commitment, has received much attention lately. However, academic research on business-to-business purchases of KIBS is narrow compared to research examining business-to-business purchases of tangible items, such as raw materials and finished products (Valk and Rozemeijer, 2009; Sheth, 1996). The unique characteristics of KIBS influence multiple aspects of the purchasing process, as certain 
dimensions become more important or difficult than in the process of purchasing goods (Axelsson and Wynstra, 2002; Smeltzer and Ogden, 2002). In comparison to the purchasing of goods, where the customer organisation can specify criteria and requirements, agreements between customers and service providers concerning KIBS are relatively ambiguous because measurements of service quality are subjective and user-dependent (Makkonen et al., 2012), and the buying organisation often cannot objectively evaluate the service provider and their offerings prior to purchase (Fitzsimmons et al., 1998).

Purchasing KIBS often requires the customer to possess considerable knowledge on various aspects of the service offerings, service provider, potential risks, costs, benefits and strategic options (Lau et al., 2003). Generally, organisational purchasing is more risky than consumer purchasing due to the high cost involved and the fact that it affects a larger group of people (Sonmez and Moorhouse, 2010). In addition, purchasing KIBS is riskier than purchasing basic or generic services due to the credence qualities and costs involved (Mitchell et al., 2003). Therefore, it is essential for buyers and suppliers to build strong, long-term relationships (Sillanpää et al., 2015). Successful service purchasing requires continuous, active interaction between all the parties involved in the procurement process (Hallikas et al., 2013). In addition, purchasing involves many interpersonal relationships between the people engaged in the purchasing process, and it is important to take into account that each of these people have unique ways of communicating, making decisions and so forth (Price and Harrison, 2009).

The main differences between this process and purchasing products are related to expectations, quality, predictability of demand, cost, verification of contract completion and payment (Sonmez and Moorhouse, 2010). Kar (2015, p. 570) states that 'product quality, delivery compliance and price are the three most important criteria for the evaluation of vendors $[\ldots]$ '. In the case of KIBS, it is often difficult for organisational buyers to analyse the value outcomes of the service in advance, and sometimes even after purchase (Valk and Rozemeijer, 2009). In other words, it is difficult to determine the value-in-use of the offering beforehand and to evaluate it objectively afterwards. When selecting a supplier, previous experience with the supplier and/or thorough assessments of the potential suppliers play a central role (Melander and Lakemond, 2014). A study by Hallikas et al. (2013) reveals that a firm's engagement in service procurement is positively related to the decentralization of the purchasing process in various locations, and to purchase services successfully, customers 
need to conduct continuous and active interactions with all the related entities which are involved in the procurement process.

Day and Barksdale (1994) have provided a comprehensive framework for the organisational buying process of knowledge-based services. Van Weele (2005) provides another framework on the same topic. For this study, we combine both the frameworks, which contain similar steps (Valk and Rozemeijer, 2009), to understand and analyse the phenomenon under study. The purchasing process begins when the customer recognises a need or problem that could be solved by purchasing knowledge-based services. Next, the customer sets purchase goals and determines specifications and creates a short list of possible service providers. The customer then makes detailed assessments of the service providers with regard to their purchasing goals and chooses the one that best fits their needs. Once a service provider has been selected, the task is assigned to that provider, and the customer evaluates, monitors and controls the quality of the service during the service creation and delivery processes. It is important to note here that assessing potential service providers prior to purchasing and evaluating the services during the service process can be difficult as knowledge-based services generally lack tangible attributes that can be evaluated objectively. Nevertheless, formal and informal evaluation also takes place after the service is completed. The customer experiences either satisfaction or dissatisfaction with the provider, which affects their future purchasing decisions (Van Weele, 2005; Day and Barksdale, 1994).

While purchasing KIBS, several other attributes have been highlighted by researchers as being important. Pearcy and Dobrzykowski (2012) stress the roles of public policy, stakeholder pressure and corporate social responsibility in doing so. Service providers should also try to reduce the buyer's perceived risk (Patala et al., 2014; Karppinen et al., 2013). In addition, business customers need to provide input at several stages of the creation and purchasing process; hence, they play multiple roles throughout the process, such as codesigner, co-developer, co-producer, co-implementer and co-marketer of services (AarikkaStenroos and Jaakkola, 2012). This further increases the complexity of the purchasing process (Valk and Rozemeijer, 2009). 


\section{METHODOLOGY}

This study is exploratory in nature and uses a qualitative case study method. The case study method allows a phenomenon to be researched in detail in a specific context (Yin, 2009). Thus, it is suitable for this study as it is performed in the context of KIBS. It is especially beneficial because the study explores organisational aspects (organisational purchasing), and the phenomenon takes place within a rich context (KIBS).

\subsection{The empirical setting}

The empirical setting for this study consists of one service provider and four of its customer organisations. The service provider offers modular engineering and consulting services. The customer organisations included in this study are engaged in metal, chemical, water supply, and security businesses. These customer organisations purchase services from the service provider for various purposes, including planning, implementing and supervising their projects.

The service provider, referred to in this study as $\mathrm{ABC}$ Engineering, is a large global service provider of modular engineering and consulting services that operates mainly on a project basis. The first customer organisation, referred to in this study as Customer 1, is a large metal manufacturer. The second customer organisation, referred to as Customer 2, is a large chemical company. The third customer organisation, referred to as Customer 3, is an SME (Small and Medium Enterprise) that supplies water and wastewater drainage and cleaning. The fourth customer organisation, referred to as Customer 4, is an SME that provides a wide range of security and other support services. The names of the case firm and its four customer firms, as well as the names of all the interviewees, will remain confidential because this enabled the case firm and its customers to share their perspectives freely and fully.

This research setting was selected for several reasons: the service offerings of the provider are highly knowledge intensive; the customer organisations possess sufficient skills, capabilities and resources to perform many of the service activities internally; and the setting allowed for data collection from both the service provider and its customer organisations. The 
collected data provided a $360^{\circ}$ perspective and, thus, an in-depth understanding of the factors that influence the purchase of KIBS.

\subsection{Data collection}

Empirical data were collected from five projects involving the service provider and its customers in which the service provider supplied crucial knowledge-intensive inputs. Data were mainly collected during face-to-face narrative interviews. Both the customers' and service provider's perspectives were obtained to provide complementary information regarding the phenomenon and to aid in data triangulation (e.g. Aarikka-Stenroos and Jaakkola, 2012). In total, 26 interviews were conducted over a period of four months. The interviews involved 16 representatives from the service provider and 10 representatives from the customer firms. The following table (Table 1) provides further information about the interviewees and their respective interviews.

Table 1. The interview details.

\begin{tabular}{|c|c|c|c|c|c|c|}
\hline \multirow[t]{8}{*}{ Organization } & Function & Field of business & Size & Interviewee & Date & Duration \\
\hline & & & & Head of business unit & 11.2 .2013 & $57 \mathrm{~min}$ \\
\hline & & & & Design manager & 11.2.2013 & $50 \mathrm{~min}$ \\
\hline & & & & Group manager & 13.2.2013 & $48 \mathrm{~min}$ \\
\hline & & & & Design manager & 5.3 .2013 & $60 \mathrm{~min}$ \\
\hline & & & & Structural engineer & 6.3 .2013 & $64 \mathrm{~min}$ \\
\hline & & & & Head of department & 13.3.2013 & $83 \mathrm{~min}$ \\
\hline & & & & Water facility engineer & 16.3.2013 & $57 \mathrm{~min}$ \\
\hline \multirow{9}{*}{$\begin{array}{l}\mathrm{ABC} \\
\text { Engineering }\end{array}$} & Service & KIBS & & Water facility engineer & 18.3 .2013 & $63 \mathrm{~min}$ \\
\hline & provider & (Engineering) & & Water facility engineer & 18.3.2013 & $65 \mathrm{~min}$ \\
\hline & & & & Group manager & 27.3.2013 & $56 \mathrm{~min}$ \\
\hline & & & & Project manager & 29.3.2013 & $73 \mathrm{~min}$ \\
\hline & & & & Structural engineer & 18.4.2013 & $60 \mathrm{~min}$ \\
\hline & & & & Head of department & 18.4.2013 & $53 \mathrm{~min}$ \\
\hline & & & & Structural engineer & 18.4 .2013 & $58 \mathrm{~min}$ \\
\hline & & & & Head of department & 19.4.2013 & $40 \mathrm{~min}$ \\
\hline & & & & Group manager & 19.4.2013 & $47 \mathrm{~min}$ \\
\hline Customer 1 & Customer & Metal & Large & Manager & 13.5.2013 & $36 \mathrm{~min}$ \\
\hline
\end{tabular}




\begin{tabular}{|c|c|c|c|c|c|c|}
\hline & & & & Head of department & 13.5 .2013 & $39 \min$ \\
\hline \multirow{3}{*}{ Customer 2} & \multirow{3}{*}{ Customer } & \multirow{3}{*}{ Chemical } & \multirow{3}{*}{ Large } & Site manager & 13.3 .2013 & $61 \mathrm{~min}$ \\
\hline & & & & Professional buyer & 13.3.2013 & $52 \mathrm{~min}$ \\
\hline & & & & Manager & 13.3.2013 & $80 \mathrm{~min}$ \\
\hline \multirow{3}{*}{ Customer 3} & \multirow{3}{*}{ Customer } & \multirow{3}{*}{ Water } & \multirow{3}{*}{ SME } & Manager & 18.3 .2013 & $37 \mathrm{~min}$ \\
\hline & & & & Head of organisation & 16.4 .2013 & $45 \mathrm{~min}$ \\
\hline & & & & Engineer & 19.4.2013 & $62 \mathrm{~min}$ \\
\hline \multirow[b]{2}{*}{ Customer 4} & \multirow[b]{2}{*}{ Customer } & \multirow[b]{2}{*}{ Security } & \multirow[b]{2}{*}{ SME } & CEO & \multirow{2}{*}{24.4 .2013} & $103 \mathrm{~min}$ \\
\hline & & & & Manager & & $\begin{array}{l}\text { (Joint } \\
\text { interview) }\end{array}$ \\
\hline
\end{tabular}

The interviews comprised open-ended questions and discussion themes, which provided several advantages: (1) interviewees' responses were not limited to predefined choices; (2) this approach uncovered various factors leading to the purchase of knowledge-intensive business services that are not mentioned in the existing literature; and (3) matters emerged that were not specifically queried. Narrative interviews thus both provided the formality required to analyse the complex phenomenon being researched and permitted the emergence of unexpected issues. Each interview was recorded with the consent of the interviewee using a digital data recorder.

In addition, also other sources of data, such as meetings, workshops, webpages and brochures, have been collected and utilised as secondary data to ensure a complete picture of the phenomenon and to support interpretation in the data analysis.

\subsection{Data analysis}

To start the analysis of the empirical data, the recorded interviews were first transcribed, resulting in 230 pages of written scripts. Next, each transcript was read carefully to obtain a first impression of the data. After gaining an overall understanding of the data, the researchers began to assign codes to specific chunks of texts, which shed light on the topic under study. The codes were not pre-determined; rather, the researchers allowed to raise them inductively from the data. Once the coding was completed, the codes and the associated strip of texts were divided into clusters based on commonalities and recurring patterns. Next, both the codes and the texts related to them were examined further to gain an appropriate understanding of each category and to ensure stable data classification. This allowed the 
researchers to identify the factors that we are looking for. The first researcher took the lead in data collection and coding, whereas the second researcher played a key role in analysing the categories and forming the conceptual understandings.

Next, the clusters were grouped into higher levels of abstraction (cf. Moeller et al., 2013). This allowed for identification of the variables that influence purchasing decisions regarding KIBS. Next, the data collected from secondary sources, including web pages, company brochures, meetings and workshops, were compared with the preliminary findings. Some dissimilarities were identified, but they were overcome by cross-checking and crossmatching. When there was any further confusion, the specific respondents from the case companies were contacted again for clarification. In the next section, the key findings are described in detail.

\section{FINDINGS}

Our analysis shows that eight different factors can influence business customers' decisions to purchase KIBS. The factors are not inclusive: not all affect a specific purchasing decision every time. Rather, any individual factor, or a combination of multiple factors, can influence the purchasing decision, and the degree of influence of any certain factor may vary.

\subsection{Convincing value propositions}

Customer organisations implement knowledge-based services to create and realise superior value in line with their business operations and strategies. The empirical data show that the service provider's ability to create convincing value propositions influences customers' perceptions of the provider's ability to achieve that objective. If the service provider can demonstrate convincing value propositions - that is, the promise that they will be able to help the customer obtain better value as a result of the service-the customer's purchasing decisions will be positively influenced. As one of the interviewees from Customer 2 stated:

The value proposition should be what we think is worth paying for-if they get ten euros from us, we should get savings of twenty euros from something else. 
Our analysis shows that creating convincing value propositions is not just helpful but is essential for positively influencing customers' perception of the provider's ability to deliver superior value, and thus to sell the services. Hence, from the service provider's perspective, both developing and offering convincing value propositions have an essential role in new customer acquisition.

\subsection{Perception of service quality}

With KIBS, it is rarely possible for customers to evaluate the quality of the services before making a purchase. Therefore, the customers' perceptions of the service quality influence their purchasing decisions. The customer's service quality perception can be formed based on several factors, including the service provider's reputation, the customer's past experiences, word-of-mouth, referrals from peers and so on. It is important to notice that service quality perception can be formed at multiple levels, from the reputations of specific individuals to the overall image of the service provider. As one of the interviewees from the service provider firm (ABC Engineering) emphasised:

First, they check firm references and they check personal references. --- If the personnel, who have references have changed, it makes selling the project much more difficult.

Hence, the perception of service quality can influence the customer's purchasing decisions in various ways. For instance, in purchasing situations in which the customer is evaluating two competing service providers, the one with better perceived service quality is often preferred.

\subsection{Perception of potential risks}

It became evident from the empirical data that organisational purchasing of services is considered risky, particularly because of its intangible nature, associated high costs, strategic importance and possible outcomes. Thus, customers' perceptions of the potential risks associated with the service may directly influence their purchasing decisions. In other words, if the risks are minimal in relation to the possible benefits of the service, customer organisations are more willing to purchase that particular service, and vice versa. One representative of $\mathrm{ABC}$ Engineering agreed: 
It is good to gain an understanding of whether the customer is satisfied [with the low risk potential], we are on the same page and we have understood what the customer wants. It is really relevant to know in the early phase.

We also found in this study that the customer's perception of potential risk diminishes if the service provider can demonstrate a proper understanding of the customer's needs in the pre-purchase phase. When the service provider was able to convince the customer that the risk potential is low, they could sell the services more successfully.

\subsection{Potential for customisation}

Knowledge intensive business services must often be customised to fit the specific needs of a customer organisation. Hence, as identified in this study, while making purchasing decisions, customers consider whether the offered services can be modified according to their needs. Services that have the potential to be customised to fit the customer's specific purposes often have a higher potential to be sold.

The service provider in our empirical case often experienced this. Their services are modular: they are divided into smaller modules rather than being sold only as a whole, and different modules can be selected in various combinations to serve the specific needs of customers. This allows service providers to serve customers according to their specific requirements. One respondent from $\mathrm{ABC}$ Engineering emphasised the importance of this:

When we operate in the industrial sector, there comes a need and it means that we quickly need to deliver what the customer wants.

It was evident that when the module combinations are able to better fit the need of a potential customer, it was easier to sell the services. However, in case of a mismatch, the service provider experienced difficulties in selling a "rather standardised" service offering. Thus, a service provider's ability to provide services that satisfy customers' specific needs has an important role in purchasing decisions.

\subsection{Quality customer relationships}

As we found out in this study, good relationships between customers and service providers have positive effects on customers' purchasing decisions to a high extent. Knowledge intensive business services providers who enjoy quality relationships with existing or 
potential customers often receive those firms' business. The head of a unit of $\mathrm{ABC}$ Engineering emphasised the role of good customer relationships in their business:

We focus on our biggest customers, keep them happy and serve [them] well. We deliver the kind of service that we have promised as well as we can, and develop that [service offering] together with the customer. That is how we gain continuity.

There are several underlying reasons for this. First, through superior customer relationships, service providers can obtain better knowledge of the customers' business processes and problems and hence can offer superior value propositions. The information flow between customer and service provider is also smoother and more frequent. In addition, customers who have good relationships with their service providers often enjoy favourable pricing.

\subsection{Individual preferences}

Empirical data shows that organisational purchasing of KIBS often includes complex interactions involving multiple personnel. At a micro level, when a customer organisation is making purchasing decisions, certain actors play more crucial roles than others. These people often hold positions of power inside the organisation, and their individual choices and preferences influence decisions regarding the purchase of KIBS. In addition, organisational systems and administrative constraints cause some purchasing decisions to be made by personnel whose opinions carry more weight than others. One interviewee from Customer 2 indicated that:

Purchases [of] over 30 euros go to the sourcing manager. It will be discussed with the sourcing manager, whether to make the purchase or not.

The empirical data show that individual preferences are closely linked with the relationship aspect of organisational purchasing. Managers with decision-making power may depend on their own choices and previous experience and thereby sidestep formal purchasing processes, such as competitive bidding, when making a purchase. One interviewee from Customer 1 said:

We did not need to put out a call for bids. We recognised that there were not that many similar service providers and the price level was normal, so we did not need to spend time on competitive bidding in the starting phase of the project. 
It is thus evident from the empirical data that individual preferences inside the customer organisation play a crucial role in the purchase of KIBS.

\subsection{Geographic proximity}

The location of the service provider can also influence purchasing decisions. Our analyses show that the creation and implementation of KIBS often involve face-to-face interactions and the transfer and application of tacit knowledge. Thus, customers often believe that service providers located in other cities or countries cannot serve them properly. One interviewee from Customer 4 emphasised the importance of location:

We chose the service provider because of [its] location is within a reasonable distance from here.

The physical distance may create challenges during problem identification, service formulation and implementation. Customers may thus choose to purchase services from nearby providers because proximity and regular face-to-face communication give them a better sense of control and security.

\subsection{Availability of information}

The empirical data suggests that purchasing KIBS requires customers to possess a considerable amount of knowledge about the service offerings, service provider, potential risks, costs, benefits and strategic options. An interviewee from Customer 2 supported this finding:

If we need to buy something, we need to have really specific information. Technical people will gather sufficient information --- to get an offer and then our internal people will possibly negotiate with the supplier.

Accordingly, the availability of appropriate and sufficient information can positively influence the customer's purchase decisions. The opposite is also true. In our case study, we found that the service provider also emphasised the importance of information availability. As one representative of $\mathrm{ABC}$ Engineering described:

Customers will change and customers' needs will change. And waiting inactively for the customer's call [to get some information] will not work. If we want to 
succeed and grow, we need to proactively provide necessary information to the customer.

If sufficient information regarding the service provider and its offerings is available, this will have a positive impact on the customer's purchasing decision because it allows the customer to make objective and informed decisions.

\section{DISCUSSION}

As business organisations are increasingly purchasing knowledge-based services from the other organisations, it is necessary to analyse the factors that influence customer organisations' decisions to purchase knowledge intensive business services. To that end, we conducted a qualitative empirical study that we expect will add to the existing knowledge on the matter and provide crucial context-specific knowledge.

In this study, we have identified eight different factors that influence business customers' decisions to purchase KIBS: convincing value propositions, perception of service quality, perception of potential risks, potential for customisation, quality customer relationships, individual preferences, geographic proximity and availability of information. Some of these factors, such as geographic proximity and availability of information, are relatively easy for customers to evaluate in advance. Others, such as the quality of the service and the associated risks, are often subjective or difficult to evaluate until the service has been provided.

These factors are diverse and multidimensional. However, they can be broadly grouped into two categories: factors that are related to the service itself and factors that are related to the service provider. Convincing value propositions, perception of service quality and customers' perceptions of risks and customisability are categorised into the first group, and customer-seller relationships, individual preferences, geographic proximity and availability of information are categorised into the second. These groups can be used to create a research framework of all the factors that influence customers' decisions to purchase KIBS (Figure 1). 


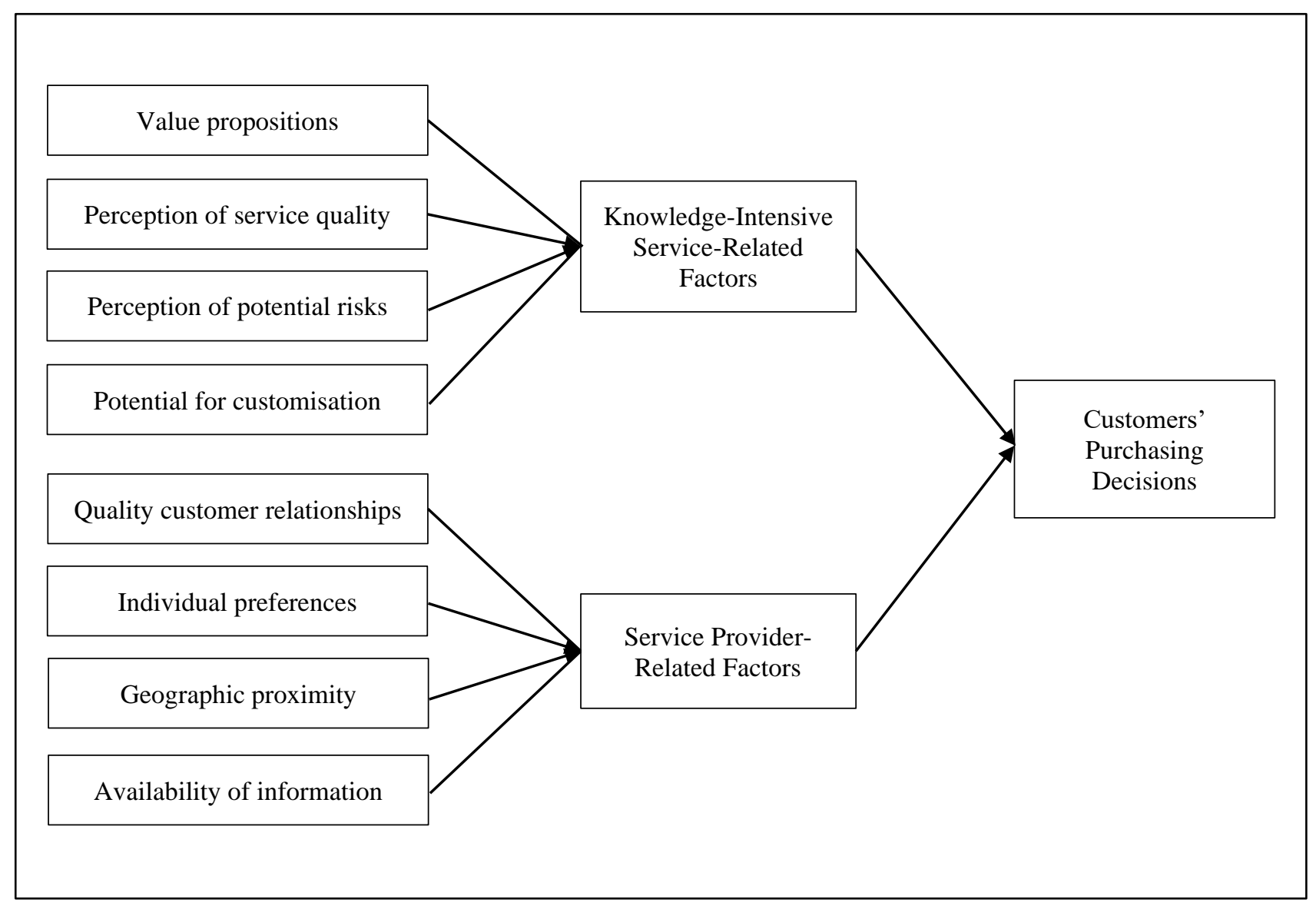

Figure 1: Relevant factors in purchasing KIBS.

However, in reality, these distinctions are not so simple and clear-cut. Individual factors such as perceived quality and individual preference, which describes how the personal choices of decision makers within a customer organisation influence purchasing decisions, can be influenced by both services and service providers.

As mentioned above, some factors, such as perception of quality or risk, are subjective and difficult to evaluate in advance due to the complex and intangible nature of KIBS. Even after a service has been purchased and implemented, its effects may be evident to customers only after considerable time has passed. Management consultancy or advertising services are good examples of such services.

The importance of studying both organisational purchasing and KIBS is supported by the extant literature. This paper will contribute to the literature and expand upon the existing knowledge of these concepts. The results of this study are exploratory. Analysing the factors that influence the purchasing of professional services or KIBS is crucial for gaining insight into the entire purchasing process of customer organisations and for providing guidelines to 
help service providers sell services that meet customers' needs and expectations. From a theoretical perspective, this study provides improved insights into the factors that influence business customers' decisions to purchase KIBS in business-to-business markets. Further, dividing factors into two categories helps simplify the factors conceptually and allows them to be explored in depth. As the factors have been examined here within the context of modular engineering services, which have received relatively little empirical attention in the marketing literature, this study also generates context-specific knowledge that contributes to the current literature.

When the findings of this study are compared with a review of the existing literature, it is evident that different factors are associated with different aspects of the purchasing process. Factors such as value propositions, availability of information, risk and quality perceptions and geographic proximity are directly connected to the detailed evaluation stage, in which the service provider is selected. However, contrary to the literature review, this study found that the relationship between customer and service provider, as well as individual preferences, can directly influence purchasing decisions, even though they are not normally part of the detailed evaluation process. This process is usually structured and formal, and it should provide a level playing field for all potential service providers. In addition, issues such as the status, phase and intimacy of the buyer-seller relationship influence which factors are emphasised during the evaluation process.

\subsection{Managerial implications}

This study also carries implications for managers. Service providers may benefit from practical insights into the factors that lead business customers to purchase KIBS because in order to succeed in business-to-business markets, selling firms must possess an understanding of customer firms' buying behavior' (Johnston and Lewin, 1996, p. 1). In certain situations, these insights may influence factors in a way that will generate favourable outcomes for service providers. An increased understanding of the entire process can also enable service providers to accurately direct marketing efforts. The findings may also help customer organisations make better-informed purchasing decisions.

Service providers should find it useful to know that customers' purchasing decisions are influenced by both the providers and the services they offer, as they can look for opportunities to improve both areas. With regard to services, service provider managers must make 
convincing value propositions and ensure that their services satisfy customers' needs. Managers should also make an effort to increase the perceived quality and decrease the perceived risks of their services. In terms of the service providers themselves, managers should emphasise building and maintaining good relationships with customer organisations and should provide them with sufficient, high-quality information. Service providers also need to know the people within customer organisations who may influence purchasing decisions. When planning for the long term, managers should consider maintaining or improving geographical proximity with their customers.

\subsection{Limitations and suggestions for future research}

In this study, the factors that influence the purchase of KIBS have been analysed at a general level. The study suffers multiple weaknesses as a result of this generalisation. It does not provide specific, detailed purchasing scenarios, which would make the findings operational (cf. Webster and Wind, 1972). The findings also cannot be quantified without further development. Nevertheless, the generalisations provide an overall perspective of organisational purchasing, which allows for an evaluation of the importance of specific variables and leads to greater insights into the antecedents of organisational purchasing of KIBS.

Geographical boundaries imposed another limitation on this study. The empirical data were collected only from Finland, making it difficult to extrapolate the findings to other geographical contexts. Collecting data only from engineering service providers and their customers created similar challenges. Similar studies should be conducted in other contexts because contextual differences may change the observed factors or make some irrelevant or introduce new ones.

In this study, the factors were examined individually. However, more than one factor can affect a purchasing decision and all are likely connected to or influenced by each other. Future studies exploring the interdependence of these factors will deepen our knowledge of this area. Also, this study focused mainly on organisational factors. However, customers' decisions to purchase KIBS can be influenced by a range of external factors, including political situation, social conditions, laws and regulations, industry practices, business environment and national economic situation. Further studies are needed to investigate the influence of these issues on business customers' decisions to purchase KIBS. 


\section{Acknowledgements}

Eija-Liisa Heikka acknowledges the financial support received from the Foundation for Economic Education and Tekes. Mekhail Mustak acknowledges Kaute Foundation, Marcus Wallenberg Foundation, and the Foundation for Economic Education for their support. The authors also wish to thank Dr. Angappa Gunasekaran and the anonymous reviewers for their valuable advices and suggestions.

\section{REFERENCES}

Aarikka-Stenroos, L. and Jaakkola, E. (2012) 'Value co-creation in knowledge intensive business services: a dyadic perspective on the joint problem solving process', Industrial Marketing Management, Vol. 41 No. 1, pp.15-26.

Atkinson, M.A. and Bayazit, O. (2014) 'A multi-criteria approach to CPA firm selection: a case study', International Journal of Procurement Management, Vol. 7 No. 1, pp.1-18.

Axelsson, B. and Wynstra, F. (2002) Buying Business Services, Wiley, Chichester.

Bettencourt, L., Ostrom, A., Brown, S. and Roundtree, R. (2002) 'Client co-production in knowledge intensive business services', California Management Review, Vol. 44 No. 4, pp.100-128.

Day, E. and Barksdale Jr., H.C. (1994) 'Organizational purchasing of professional services: the process of selecting providers', Journal of Business and Industrial Marketing, Vol. 9 No. 3, pp.44-51.

Den Hertog, P.M. (2000) 'Knowledge-intensive business services as co-producers of innovation', International Journal of Innovation Management, Vol. 4, No. 4, pp. 491-528.

Dholakia, R.R., Johnson, J.L., Bitta, A.J. and Dholakia, N. (1993) 'Decision-making times in organizational buying behavior: an investigation of its antecedents', Journal of the Academy of Marketing Science, Vol. 21 No. 4, pp.281-292.

Ellram, L.M. and Zsidisin, G.A. (2002) 'Factors that drive purchasing and supply management's use of information technology', IEEE Transactions on Engineering Management, Vol. 49 No. 3, pp.269-281. 
Eriksson, K. and Vaghult, A. (2000) 'Customer retention, purchasing behavior and relationship substance in professional services', Industrial Marketing Management, Vol. 29 No. 4, pp.363-372.

File, K.M., Cermak, D.S. and Prince, R.A. (1994) 'Word-of-mouth effects in professional services buyer behavior', The Service Industries Journal, Vol. 14 No. 3, p.301.

Fitzsimmons, J.A., Noh, J. and Thies, E. (1998) 'Purchasing business services', Journal of Business and Industrial Marketing, Vol. 13 No. 4/5, pp.370-380.

Hallikas, J., Kulha, T. and Lintukangas, K. (2013) 'The characteristics of service buying in the business-to-business sector', International Journal of Procurement Management, Vol. 6 No. 3, pp.280-296.

Hallikasa, J., Immonen, M., Pynnönen, M., Mikkonen, K. (2014) Service purchasing and value creation: Towards systemic purchases, International Journal of Production Economics, Vol. 147 Part A, pp. 53-61.

Johnston, W.J. and Lewin, J.E. (1996) 'Organizational buying behavior: toward an integrative framework', Journal of Business Research, Vol. 35 No. 1, pp.1-15.

Kar, A.K. (2015) 'Reinvestigating vendor selection criteria in the iron and steel industry', International Journal of Procurement Management, Vol. 8 No. 5, pp.570-586.

Karppinen, H., Huiskonen, J. and Seppänen, K. (2013) 'Service designs and mindsets: extracting experiential knowledge from service realisation', International Journal of Procurement Management, Vol. 6 No. 5, pp.561-577.

Kohli, A. (1989) 'Determinants of Influence in Organizational Buying: A Contingency Approach', Journal of Marketing, Vol. 53, No. 3, pp. 50-65.

Kowalkowski, C., Kindström, D. and Brehmer, P.O. (2011) 'Managing industrial service offerings in global business markets', Journal of Business and Industrial Marketing, Vol. 26 No. 3, pp.181-192.

Lau, G.T., Razzaque, M.A. and Ong, A. (2003) 'Gatekeeping in organizational purchasing: an empirical investigation', Journal of Business and Industrial Marketing, Vol. 18 No. 1, pp.82103. 
Lian, P.C. and Laing, A.W. (2007) 'Relationships in the purchasing of business to business professional services: the role of personal relationships', Industrial Marketing Management, Vol. 36 No. 6, pp.709-718.

Makkonen, H., Olkkonen, R., and Halinen, A. (2012) 'Organizational buying as muddling through: A practice-theory approach', Journal of Business Research, Vol. 65 No. 6, pp. 773 780.

Matthyssens, P. and Vandenbempt, K. (2008) 'Moving from basic offerings to value added solutions: strategies, barriers and alignment', Industrial Marketing Management, Vol. 37 No. 3, pp.316-328.

Melander, L. and Lakemond, N. (2014) 'Variation of purchasing's involvement: case studies of supplier collaborations in new product development', International Journal of Procurement Management, Vol. 7 No. 1, pp.103-118.

Miles, I. (2005) 'Knowledge intensive business services: prospects and policies', Foresight, Vol. 7 No. 6, pp.39-63.

Miles, I., Kastrinos, N., Flanagan, K., Bilderbeek, R., Den Hertog, P., Huntink, W. and Bouman, M. (1995) Knowledge-intensive business services, EIMS Publication, No. 15.

Miozzo, M. and Grimshaw, D. (2005) 'Modularity and innovation in knowledge-intensive business services: IT outsourcing in Germany and the UK', Research Policy, Vol. 34 No. 9, pp.1419-1439.

Mitchell, V.W., Moutinho, L. and Lewis, B.R. (2003) 'Risk reduction in purchasing organisational professional services', The Service Industries Journal, Vol. 23 No. 5, pp.1-19.

Moeller, S., Ciuchita, R., Mahr, D., Odekerken-Schröder, G. and Fassnacht, M. (2013)

"Uncovering collaborative value creation: Patterns and establishing corresponding customer roles", Journal of Service Research, Vol. 16 No. 4, pp. 471-487.

Muller, E. and Doloreux, D. (2009) 'What we should know about knowledge-intensive business services', Technology in Society, Vol. 31, pp.64-72.

Pardos, E., Gómez-Loscos, A. and Rubiera-Morollón, F. (2007) “"Do versus buy” decisions in the demand for knowledge intensive business services', The Service Industries Journal, Vol. 27 No. 3, pp.233-249. 
Patala, S., Jalkala, A. and Soukka, R. (2014) 'Methods for reducing buyer perceived risk related to the adoption of technological innovations', International Journal of Procurement Management, Vol.7 No.1, pp.71-84.

Pearcy, D.H. and Dobrzykowski, D.D. (2012) 'A service-dominant logic analysis of fair trade procurement management', International Journal of Procurement Management, Vol. 5 No. 4, pp.517-541.

Price, P.M. and Harrison, N.J. (2009) 'Purchasing and personality: a review of the literature and a case for further research', International Journal of Procurement Management, Vol. 2 No. 1, pp.62-78

Sheth, J.N. (1973) 'A model of industrial buyer behavior', Journal of Marketing, Vol. 37 No. 4, pp.50-56.

Sheth, J.N. (1996) 'Organizational buying behavior: past performance and future expectations', Journal of Business and Industrial Marketing, Vol. 11 No. 3/4, pp.7-24.

Sillanpää, I., Shahzad, K. and Sillanpää, E. (2015) 'Supplier development and buyer-supplier relationship strategies: a literature review', International Journal of Procurement Management, Vol. 8 No. 1/2, pp.227-250.

Smeltzer, L.R. and Ogden, J.A. (2002) 'Purchasing professionals' perceived differences between purchasing materials and purchasing services', Journal of Supply Chain Management, Vol. 38 No. 4, pp.54-70.

Sonmez, M. and Moorhouse, A. (2010) 'Purchasing professional services: which decision criteria?', Management Decision, Vol. 48 No. 2, pp.189-206.

Valk, W. and Rozemeijer, F. (2009) 'Buying business services: towards a structured service purchasing process', Journal of Services Marketing, Vol. 23 No. 1, pp.3-10.

Van Weele, A.J. (2005), Purchasing and Supply Chain Management: Analysis, Strategy, Planning and Practice, Thomson Learning, London.

Verville, J., Bernadas, C. and Halingten, A. (2005), 'So you're thinking of buying an ERP? Ten critical factors for successful acquisitions', Journal of Enterprise Information Management, Vol. 18 No. 6, pp.665-677.

Webster Jr., F.E. and Wind, Y. (1972) 'A general model for understanding organizational buying behavior', Journal of Marketing, Vol. 36 No. 2, pp.12-19. 
Wittreich, (1966), 'How to buy/sell professional services', Harvard Business Review, Vol. 44 No. 2, pp. 127-136.

Yin, R.K. (2009) Case Study Research: Design And Methods, $4^{\text {th }}$ ed., Sage Publications, USA. 